\title{
Innu Oral Dominance Meets Schooling: New Data on Outcomes
}

\author{
Barbara Burnaby and David Philpott \\ Faculty of Education, Memorial University of Newfoundland, \\ St John's, Newfoundland and Labrador, Canada
}

In light of a major study on educational outcomes, this paper explores how Aboriginal language dominance and virtually exclusive use of oral communications in one Aboriginal group has been affected by its interaction with Western institutions. For several years negotiations have been undertaken among the Innu Nation of Labrador, the province of Newfoundland and Labrador, and the federal government over band status for the Innu, reserve creation and the development of locally controlled institutions. As part of the negotiations, a series of studies with Labrador Innu children, their families and teachers have produced rare data on Aboriginal children in relation to their schooling. The paper sketches factors relating to the history and practice of formal, Western schooling in Canada, followed by indicators of Canadian Aboriginal people's responses to schooling. A brief description follows of the Innu of Labrador, emphasising their unique history relative to Canadian Aboriginal groups in general. Following this, data from the recent study are outlined, providing evidence of almost complete failure of schooling for the Innu. Finally, these data are discussed as insights into how the Innu, and those responsible for providing schooling for them, value and react to factors in the situation.

\section{doi: $10.2167 / j m m d 494.0$}

Keywords: indigenous languages, literacy, Aboriginal education, bilingual education

As rapid world changes in governance, economies, transportation, communications and the like are affecting not only urban areas but remote ones as well, no one is untouched. This paper explores evidence of current Western and Aboriginal interaction and negotiation of meaning around institutions, particularly public schooling. Specific reference will be given to a major study on educational outcomes for the Innu people of Labrador as an example of the impact of Western institutions on minority culture and language. The authors have both been involved for several years in the process of negotiations among the Innu Nation of Labrador, the province of Newfoundland and Labrador, and the federal government over band status for the Innu, reserve creation and the development of locally controlled institutions. In this discussion, education has been by far the most prominent institution. As part of the negotiations, Philpott and colleagues have recently conducted a series of studies with Labrador Innu children, their families and teachers, which have produced rare data on Aboriginal children in relation to their schooling. Chief among these data were multiple indicators on the current attendance and achievement for Innu children, as well as communities' attitudes towards and aspirations for schooling. What emerges from this study are strong issues about how the 
value and meaning of formal schooling has been and is being negotiated between the Innu and those charged with providing it. While not presented for comparison purposes with the circumstances of other Aboriginal people, it does provide a reflection on context and meaning. The data provide extensive information, described by community, gender and age level of a small and highly recognisable population of children who have received significant media attention in recent years. Therefore, specific disclosure of details of outcomes must be tempered with concern for confidentiality. Thus, this paper will discuss broader findings and argue for generic implications of such a concerning profile of learner need.

In this context, the most simplistic definition for oral dominance will be used; namely that the Innu have had no meaningful community experience with literacy in their traditional language or English, or its promotion through schools. While some sociolinguistic work with the Innu has been completed (Drapeau, 1984a, 1984b, 1995; Mailhot, 1997), this work has mostly been done among the Innu of Quebec who, while close to their Labrador counterparts, have had greater contact with mainstream Canadian culture. Also, the factor of literacy has rarely been touched in these studies (see however, Drapeau, 1992; Mailhot, 1985). A direct comparison with the Quebec Innu is not possible as they have enjoyed greater experiences, both in community and in school, with literacy in their both their first language and their second language (French). We do however begin with a sketch of factors relating to the history and practice of formal schooling in Canada, followed by indicators of Canadian Aboriginal people's responses to it. So as to contextualise the interaction of a largely oral culture with contemporary educational institutions, we give a brief description of the Innu of Labrador, emphasising their unique history relative to Canadian Aboriginal groups in general. Following this, an overview of the data from the study by Philpott et al . $(2004,2005)$ is outlined. Finally, we discuss these data as indicators of how the Innu and those responsible for providing schooling for them value and react to factors in the situation.

\section{Factors in the Model of Western Schooling}

Because schooling is one of the largest and most pervasive institutions in Canadian society today, there is the temptation to think of it as more clearly structured and stable than it is. While the Innu of Labrador will be later discussed as a powerful example of failure of education to earn a place within Aboriginal culture, a brief history of the evolution of educational services in general is warranted. The development of universal, compulsory and publicly funded schooling arose in the second half of the 19th century in the wealthiest and most Westernised countries. It slowly evolved over the next century to rework and/or replace the existing patchwork of educational provisions for children which included schooling run by religious organisations, private educators and community-organised classes. In Canada, the British North America Act of 1867 assigned the provinces/territories responsibility for public education creating separate, albeit similar, histories.

Over the ensuing 100 years, until the mid 1900s, there were various central tasks addressed in developing universal public education. One of these tasks 
was to separate or at least stabilise the traditional interests of Church and State in this endeavour, a task not entirely concluded; its remnants are still enshrined in legislation and practice. Another was to set parameters and standards for the content and expected outcomes of schooling. In the hundred years in question, a sense of public curriculum for all children slowly emerged. An important challenge was how to reconcile previous approaches to schooling that included the privileging of the children of the elite as well as preparing the lower classes to fit into expected roles in the developing economy. The general approach was the creation of standards, and those pupils who did not reach those standards 'failed'. As part of this enterprise, forms of evaluation of pupils began to emerge, usually culminating in public examinations at the end of high school. Competition was encouraged, and excellence in terms of the achieving those standards was the goal (Brehaut, 1984). Over this period, there were groups that the system excluded from these standards, and separate models were created (some temporary) for marginalised groups such as some orphans, children with disabilities and, as we will consider below, Aboriginal children (Burnaby, 1999). In other cases, children who differed in some respects from the norm, for example Francophones outside of Quebec, were required to fit the mould without regard for their different needs and interests. Another challenge was to implement schooling universally, spreading from urban areas and towns to remote areas of the country. Yet another challenge was the standardisation of training for teachers and emerging disciplines such as psychology, linguistics and anthropology were constantly influencing model(s) of public education. For example, research was initiated into how children learn to read, how second languages are learned and how learning can be assessed (e.g. Howatt \& Widdowson, 2004).

After the Second World War, major changes to the models of public education occurred. The full implications of what 'universal' and 'publicly funded' meant in terms of schooling were starting to be addressed. A strongly influential document was the so-called Hall-Dennis Report in Ontario (Ontario Department of Education, 1968) which promulgated the notion that all children have unique needs, interests and strengths. This perspective influenced public schooling to focus on assisting children in developing their individual potential rather than (only) meeting pre-set, external goals. Implications included elaborated policies on curriculum, and research on means of assessing progress, the effects of teaching methods and remediation for children who were falling behind in learning. Public examinations at high school exit were mainly abandoned, and the 'social promotion' of children who were having difficulty learning largely replaced the practice of holding children back a grade. The professionalisation of teachers, including a required university degree for teachers in elementary schools, was launched in the 1970s. The development of education as an academic focus was linked to this development. As some community institutions, such as formal religion, the extended family and the stay-at-home mother, waned in prevalence, increasing demands were made on public education to ensure that children were socialised on a wide variety of issues from sex education to driver training. With respect to children who deviated from the norm, post-war 
immigration patterns and subsequent changes in immigration policy, as well as the passing of the Official Languages Act in the 1960s, resulted in some educational practices and policies to address the needs of children who do not speak the language of instruction as a mother tongue (e.g. Burnaby et al., 2000). Languages of study began to include the second official language and immigrant languages present in the community. Also, a movement starting in the 1980s began the process of integrating children with special needs into regular classrooms. It was only in these post-war years that schooling according to province-wide standards reached the more isolated communities of the country. Finally, the rapid rise in requirements for formal education credentials in the labour force has been putting increasing pressure on schooling to meet public expectations. This factor has led to public and institutional struggles over 'back to the basics' standards, and broad attempts at normative testing, which conflict with emerging principles and practices concerning children's individual differences.

The province of Newfoundland and Labrador has followed this educational path, with perhaps more challenge than most. In its rural and isolated population, which valued kinaesthetic skills required in the primary industries of fishing and forestry, formal education was a luxury few could afford. When the province joined confederation in 1949, high infant mortality rates, poor health services and low literacy levels typified the former British colony. Education, as in its Canadian counterparts, became a provincial responsibility under Confederation, but the Terms of Union retained Newfoundland's confessionally based school system under the aegis of seven Christian denominations (Encyclopaedia of Newfoundland, V.5). Nonetheless, confederation resulted in an influx of money that would fund the creation of educational services that led to '... an economic and psychological revolution that would create the cultural flowering which has transformed the face of Newfoundland since 1949' (Rowe, 1973: 12). This system would parallel the evolution of education in Canada, including the school reform movement of the 1980s that led to the removal of denominational education, radical restructuring of curriculum and management systems and a streamlined curriculum (Philpott \& Nesbit, 2002).

Clearly, schooling as a multifaceted institution of socialisation of children for adult life is value-laden, complex and constantly evolving. For the purposes of the following discussion, salient points here include: (1) universal, publicly funded schooling is based on an extremely broad set of principles (including Christian ones), but their application continues to reflect enormous conflicts over public responsibility and the goals and parameters of schooling; (2) although public schooling has slowly come around to recognising in principle the unique needs of and public responsibility for specific, marginalised racial, cultural, abled and linguistic groups, measures to put these principles in practice are still contentious and under development; (3) jurisdictional separation of responsibility across provinces, between the federal and provincial governments, and among groups advocating about specific aspects of schooling has led to a confusing pool of information about the actual outcomes of formal education. In sum, there is at least as much heat as light to inform judgements about general, as well as specific, aspects of public 
schooling in Canada. Central to this current discussion is an emphasis that schooling for the population in Labrador (Innu and others) has had more complexities and challenges than in most locations in North America.

\section{Factors in Education Specifically for Aboriginal Children in Canada}

Because Aboriginal peoples ${ }^{1}$ in Canada represent perhaps the extreme in marginalisation of Canada's societal groups, they have been treated in highly varied ways relative to Western approaches to schooling. Thus, the history of and research on schooling for Aboriginal children is much more complex than that of public schooling in general. Therefore, for the purposes of the present paper, we confine our discussion of Aboriginal schooling to several dominant, though highly generalised, points to provide a basis for the case study data to follow.

\section{Marginalisation of Aboriginal peoples, as a group, in Canadian schools}

Over the period of contact between Aboriginal people in Canada and nonindigenous settlers, Aboriginal people have been more strongly marked as 'the Other' from Western Canadian perspectives than any other group. The fact that they have been treated as wards of the state in most of their relations with Euro-Canadian officials still leaves its mark. Early colonial governments in what is now Canada dealt with Aboriginal issues through the military until about 1830, when civilian agencies took over. A central factor is that, while education was the responsibility of the provinces/territories, the federal government retained jurisdiction over 'Indians' and Indian lands (s.91 (24) including education (s.93)). The effect of this division was that the education of Aboriginal peoples was, and is, the only children's educational jurisdiction the federal government officially has. In 1876, the first version of the Indian Act was passed federally. Since that time a large proportion of Aboriginal people have been legally distinguished from the rest of Canadian citizens by their Indian status. 'Status Indians' have received unique treatment by governments while other Aboriginal Canadians have been dealt with mostly under the provisions for the rest of the population. Given such ease of identification, the conditions and treatments of status Indians have been much better documented.

The impact of this legal structure on schooling for Aboriginal children has been enormous. The Indian Act originally mentioned the provision of schools as buildings but, in frequent amendments to the Act, an elaborate set of statements on federal responsibility for education of 'Indians' evolved (ss. 114-123). As the federal government otherwise had no responsibilities for education, it was not motivated to develop its own system of education just for Indians. Until the 1960s, it discharged its responsibilities by continuing the existing practices for providing education to status Indian children by granting funds to Christian organisations to carry out this duty. After a failed attempt in the 1950s and 1960s to hand over the work of Aboriginal schooling entirely to the provinces (see Hawthorne, 1967), the federal government 
undertook to run schooling for many status Indians itself. A further attempt to devolve all but the fiscal responsibility for treaty Indians from the federal government to the provinces in 1969 was strongly resisted by Aboriginal groups. The current result is a variety of Aboriginal schooling circumstances including: band-controlled schools with federal funding; tuition agreements to fund the attendance of status Indian children in provincial schools; and the attendance of status Indian and other Aboriginal children in provincial schools without federal funding. Aboriginal children in provincial schools are not counted as such unless they self-identify and, fearing legal repercussions, schools hesitate to identify any children by race or ethnicity.

Various surveys of curriculum modifications to accommodate the language and cultural needs/interests of Aboriginal children, whether status or not (Assembly of First Nations, 1990; Burnaby, 2002; Kirkness, 1992; Royal Commission on Aboriginal Peoples, 1996; Task Force on Aboriginal Languages and Cultures, 2005) are much more likely to be present in band-controlled schools and, to a lesser extent, in provincial schools with Aboriginal children funded under federal funding agreements, than they are in provincial schools where Aboriginal children are just a regular part of the school population. Some provinces have developed a curriculum specifically for Aboriginal students, but this appears to be largely available on a discretionary basis and not widely used (Burnaby, 2002). With half of Aboriginal students now living off-reserve, this curriculum is limited in application to schools in small, rural communities or inner city schools with high Aboriginal enrolment. While training for Aboriginal teachers is carried out under provincial regulations in university faculties of education, professional development and other resources for Aboriginal teachers are notably scarce.

\section{Evidence of Aboriginal people's views on schooling}

There is very little comprehensive documentation of Canadian Aboriginal people's views on schooling. In this section, we do, however, provide a few glimpses of Aboriginal people's probable attitudes to formal education. As noted, evidence on 'status Indians' is more common than that for other Aboriginal Canadians. Governments and Christian mission societies have provided schooling for and proselytised to various Aboriginal groups since the 17th century (Burnaby, 1980: 34-36; Kirkness, 1992: 7; Tschantz, 1980: 3ff). Schooling was seen by authorities in most parts of the British Empire as the way to civilise indigenous peoples. However, there was clear conflict between the task of propagating Christianity and defending the cultural and linguistic habits of the Aboriginal community (Phillipson, 1992: 115). Some missionaries did create effective systems of schooling for Aboriginal groups that encompassed a great deal of the indigenous language and culture (e.g. Bragdon, 2000; Greenfield, 2000; Hart, 2000). A significant example in Labrador is the role of schooling in the work of the Moravians among the Inuit since the 1770s (McGrath, 1991-92). Despite this conflict over cultural retention, education was valued by these people, as witnessed in all of the treaties signed since the original Indian Act mentioned provisions for maintaining schools (MacPherson, 1991: 7). Such a consistent focus on negotiating educational provisions for their children implies 
more than a passing interest in schooling on the part of the Aboriginal signatories as well as the non-Aboriginals.

As the federal government experimented with the potential of devolving Aboriginal education to the provinces in the two decades after the Second World War, the study commissioned by the federal government to examine Aboriginal governance and services, including schooling (Hawthorne, 1967), outlined problems with existing provisions despite a generally positive attitude on the part of Aboriginal communities to having their children schooled. When the federal government directly proposed devolution of administration of services for Aboriginal peoples to the provinces, the newly formed organisation representing status Indians, the National Indian Brotherhood, chose education as the main topic on which to respond. In its document, Indian Control of Indian Education (1972), it emphasised the importance of schooling to Indian communities as well as a model that would respect and preserve Aboriginal languages and cultures and also to prepare children to make a good living in the broad Canadian society. Further documents (e.g. Assembly of First Nations, 1988, 1990; Hughes, 1990; Royal Commission on Aboriginal Peoples, 1996; Task Force on Aboriginal Languages and Cultures, 2005) reinforced the position that Aboriginal peoples in Canada prize good and successful education for their children despite their ongoing concerns for quality of service. However, these documents blamed the system of residential schooling for Canadian Aboriginal peoples in the first half of the 20th century for a number of current problems in Aboriginal communities including the decline of most native languages and the rising social disruption.

In sum, it appears that Aboriginal people have, in general, taken a positive attitude to the value of schooling for their children. What they have been less positive about is the effect that Eurocentric models of education, certainly those blatantly devoid of any Aboriginal cultural/language content, has had on their people.

\section{Evidence of outcomes of schooling for Aboriginal children}

Schooling for status Indians in Canada has largely been substantially different from that of other children. In fact, the concerns are so pronounced that in 2004, the Council of Ministers of Education would make the following statement:

There is recognition in all educational jurisdictions that the achievement rates of Aboriginal children, including the completion of secondary school, must be improved. Studies have shown that some of the factors contributing to this low level of academic achievement are that Aboriginals in Canada have the lowest income and thus the highest rates of poverty, the highest rate of drop-outs from formal education, and the lowest health indicators of any group. (Council of Ministers of Education, 2004: 22)

While statistics on factors such as high school graduation have indicated a slow closing of the gap between Aboriginal children and all other Canadian children, the Office of the Auditor General of Canada (2004) would also name 
concern by stating: 'We remain concerned that a significant education gap exists between First Nations people living on reserves and the Canadian population as a whole and that the time estimated to close this gap has increased slightly, from about 27 to 28 years' (Section 5.2). These calculations are based on Status Indian children whose education is funded directly by the federal government. We have no clear way of knowing whether Aboriginal children not so identified perform better.

Aboriginal languages in Canada have declined dramatically in the past five or six decades (Norris, 1998). The Task Force on Aboriginal Languages and Cultures (2005: 57) views the situation as:

In sum, the studies and surveys considered by the Task Force portray a multi-dimensional picture of First Nation, Inuit and Métis languages spoken, in some cases only by a few Elders, and in other cases by tens of thousands of people. Some of the 61 First Nation, Inuit and Métis languages have withstood tremendous pressures, continuing to be used in homes and in the communities. More commonly spoken languages such as Inuktitut, Cree, Ojibwe and Montagnais-Naskapi are viable, having at least 25,000 speakers ranging from the young to the elderly. However, consultations and local language surveys and studies showed that all languages, including those considered 'viable,' are losing ground.

This Task Force, and many other reports, indicate that Aboriginal people strongly blame the residential schools for this decline in their languages.

In sum, reliable data on outcomes of education for Aboriginal children do not give a comprehensive picture of actual situations in light of the many differences in treatment as well as community circumstances that exist. Although the federal government, by providing education specifically for many Aboriginal children, was in a position to tailor that education to meet the unique needs and interests of Aboriginal children and their parents, it seems to have for the most part taken a punitive and authoritarian stance. In other words, it has treated Aboriginal children, particularly status Indian children, as 'the Other', and has enforced policies to try to make them fit the mainstream norms. At the same time, provincial school systems have done little to modify the hierarchical, Euro-Canadian model, separate Church and State, recruit qualified teachers and adopt curricula that might allow Aboriginal children to be included in the general economic systems of the country. Nonetheless, Aboriginal parents have indicated over the years their belief in the value of a good education for their children. In light of the evident failure of schooling for Aboriginal children, it is remarkable that Aboriginal leaders still look to the school as a major resource in furthering their language maintenance and revitalisation initiatives. It is against this backdrop of evolving paradigms of education for Canada's Aboriginal population and the profound impact that a colonised approach towards assimilation has had, that we turn our attention to one specific group, the Labrador Innu, who are perhaps the last to make contact with the dominant Canadian culture (Mailhot, 1997). Although educational institutions, including those in Labrador, have struggled to earn a place in many Aboriginal communities, for 
the Innu, the failure is dramatically more significant (Press, 1995; Samson, 2000/2001).

\section{The Innu of Labrador in Context}

The Innu, an Algonquian language speaking group of Amerindians, have tended to travel and hunt inland in Quebec and Labrador and down the waterways to the Lower North Shore of the St. Lawrence River. Migratory patterns, harsh climate and challenging geography would lead to a group of Innu becoming more isolated from their Quebec cousins. These Labrador Innu lived largely through harvesting from the land within their community rules of governance and traditional knowledge resources (Mailhot, 1997). The first documented contacts between the Labrador Innu and Europeans occurred in the early 1700s where the Innu, who were engaged in caribou hunting inland, would occasionally travel to the coast to trade. As European trading posts became more established, missionaries started arriving to serve employees of the posts as well as to convert the Aboriginal people. The Innu migrations to these posts gradually became more routine and with this came more regular interactions with the missionaries who, by now, were making a more concerted effort towards conversion. By the 1860s, most Innu had been converted to Christianity at these missions, which involved religious observances and some efforts towards the teaching of literacy. While records indicate that these missions were successful in teaching some Innu to read in their own language by 1851, by 1893 the missions had ceased, with the Innu then served by priests from Newfoundland (Mailhot, 1997: Ch. 1). In sum, the Innu who stayed mostly in the interior had considerably less contact with Europeans than did those who spent more time on the coast of the St. Lawrence. Second language would also begin to differentiate them from their Quebec relatives through the expressed teaching of English instruction, limited as it was.

It wasn't until the Newfoundland government's policies on assimilation in the 1950s and 1960s that settlement of the Labrador Innu into communities began and with it, the erosion of traditional hunting and lifestyle practices. In Northern Labrador, a group of Innu, under government pressure, settled in Davis Inlet (Armitage, 1997), an island where they were physically isolated from their hunting land and with limited supplies of fresh water. This group would become known as the Mushuau Innu and would eventually receive international attention for the squalid living and social conditions that this forced settlement would foster. Further south a second community, Sheshatshiu, would be settled with government arranged houses, a school and various government services for the Innu who were living and hunting in that area (Mailhot, 1997). They too would go on to receive national and international media attention for both their own harsh social conditions as well as their organised opposition to low-level flying at the air base in Goose Bay and the negative effects that hydroelectric development would have on their traditional hunting grounds. In fact, the Innu's conflict with Western institutions would become so pronounced that they would be eventually referred to in contemporary media as 'Canada's Tibet' (Samson, 2000/2001). The Innu left 
their nomadic ways and economy largely because of the attraction of the availability of government services that they could access if they settled in villages. However, their subsequent economic marginalisation has left them in a dependent status with respect to those in economic and political power, and the services available to them have been minimal at best. In addition to the educational problems discussed below, housing and water and sewage services are at a deplorable level in Sheshatshiu and were in Davis Inlet until that community was moved to its new site of Natuashish (established by the federal government in 2002).

Currently, most of the approximately 2500 Innu in Labrador live in Sheshatshiu or Natuashish, while a smaller number live in other communities throughout the region. (About 11,000 more Innu, who are relatives of the Labrador group, continue to live in Quebec.) Life in contemporary communities, which includes air travel, roads, telephones and electricity as well as compulsory schooling and other government services such as health care, had a major impact on their former nomadic, hunter-gatherer, fur-trading lifestyles. Elected band councils and an Innu political organisation (now called the Innu Nation) were initiated in the 1970s. Money gradually became the medium of exchange in the economy, and hunting is practised less frequently, though many Innu continue to spend extended time 'on the land'. Labrador is still poorly serviced by roads; Sheshatshiu is on a road and is across a river from the mixed race community of Northwest River, but Natuashish on the north coast is reached by air year round and a coastal ferry service in summer.

Despite all these changes, Mailhot (1997) notes the strong persistence of a number of cultural traits among the Innu such as affinity with historical family groups (Ch. 2), sharing of physical resources (p. 69), distribution of favours among kin (pp. 54-55), recognition of elders, (p. 79), travelling widely in their former territory (p. 129), naming practices (pp. 96), rules of hospitality (p. 166) and the like. However, these and other traditional traits come into conflict with their counterparts in Euro-Canadian society with resulting 'difficult material circumstances, poverty, inadequate food, alcohol abuse, violence, delinquency, problems with the law, and the erosion of their culture, language, and value system' (Mailhot, 1997: 152). Included in this conflict would be significant struggles with formal schooling.

Nonetheless, the Innu in Labrador are in an enviable position compared to the vast majority of Aboriginal people in Canada in that virtually all of them are mother tongue speakers of their traditional language, Innu-aimun. The 2001 Canadian census data (Statistics Canada, 2003a) indicate the almost complete fluency in Innu-aimun of the populations of Sheshatshiu and Davis Inlet (where the people who now live in Natuashish lived in 2001). Of the 11,000 Innu who live in Quebec, their numbers of mother tongue speakers vary by village from none in one village to about $80 \%$ in another. Innu children in Labrador are almost all raised in households where Innu-aimun is spoken as the first language of communication and in a community in which Innuaimun is the medium of communication for intimate and informal purposes and in some services and workplaces. However, recently there has been concern voiced that a considerable number of the younger children are not speaking Innu-aimun as much any more, but there is little evidence of a 
corresponding increase in their English skills. Many adults are bilingual in English and Innu-aimun, but others are monolingual in Innu-aimun; on the 2001 census, 320 (21.3\%) of Innu-aimun mother tongue speakers in Labrador reported that they spoke neither English nor French. Among mother tongue speakers of Aboriginal languages as a whole in Canada, only $8 \%$ speak neither English nor French (Statistics Canada, 2003b).

While there is an orthography for the language, very few Labrador Innu adults or children have any proficiency in using it and it is not the medium of any active communication. As is common elsewhere, there are tensions in the community about orthographic standardisation (Burnaby, 1985; Francis \& Reyhner, 2002: 152). Critically, the Labrador Innu have virtually no experience of literacy in their own language and therefore literacy in Innu-aimun has no practical role in communications in their communities. There has been virtually no accommodation to this linguistic reality on the part of non-Innu who live and work in the community or provide services in the region. While publicly funded schooling was available to them in English, it was the same as that for other children in the province despite the clear language and cultural differences. It comes as no surprise that numerous studies have laid blame on both the federal and provincial governments for critical neglect in the Innu situation (e.g. Backhouse \& McRae, 2002; Tanner et al., 1994).

In sum, the Innu of Labrador, relative to Aboriginal peoples in most parts of Canada, have had more than a passing contact with non-Aboriginal people only in the past few decades. It is just 40 years or less since they have settled in communities and have only since then been exposed to schooling and other government services. Thus, the Innu of Labrador, considered by many to be those Aboriginal people in North America least affected by European contact (Mailhot, 1997: 64), are now in the position of having to adjust most quickly.

\section{Innu Educational Circumstances}

The two communities of Natuashish and Sheshatshiu have in recent years created separate Band Councils despite sharing a common history and language. While this history is marked by pronounced conflict with Western cultural institutions from first contact, their experience with Western schooling came to typify a cultural and linguistic mismatch with many long-term effects on these people. When Newfoundland and Labrador joined the Canadian federation, the agreement was that all inhabitants, including those of Aboriginal descent, would be treated the same under provincial jurisdiction, but that the federal government would regularly compensate the provincial government for providing services relating to the specific needs of the Aboriginal peoples. Thus, Aboriginal children in the province have mostly been attending schools run by provincial school boards in the past few decades.

The old colony and new province of Newfoundland and Labrador had significant challenges. The province has been relatively poor, non-industrialised and with a small rural population. Importantly, the province has very little ethnic/racial variety in its mainly Anglo-descended population. Thus, the need for linguistic, ethnic or racial inclusivity measures in education has never 
been a high priority. Newfoundland insisted on retaining it denominational school system after Confederation until the late 1990s (McCann, 1998), which contributed to the colonial approach to education of these people. While the province has not had the political pressure, or the interethnic experience or resources to make nuanced initiatives to meet the schooling needs of the Innu in Labrador, the extent to which active racism was a factor cannot be determined.

Subsequently, under provincial jurisdiction, English-medium schools were operated in both Innu communities by the Catholic School Board, staffed by English-speaking teachers. Thus, Innu students would enter school fluent in their native language and meet teachers fluent only in English. Instruction on the provincially prescribed curriculum was in English, with scant and inconsistent attempts at mediation in the first language. So blatant were the resultant concerns that education, particularly issues relating to school attendance and success, would eventually become a dominant item in reserve status negotiations. Attendance at the school had been reported to be at a shocking $40 \%$ for at least a decade. No other schools in the province, including those that have mainly Aboriginal pupils, has a record of less than $80 \%$ school attendance (Department of Education, Newfoundland and Labrador 2005). From the non-Innu point of view, poor scholastic outcomes and high rates of absenteeism in both community schools invited disparaging perceptions concerning the importance of formal education to the Innu people and the effects of a cultural mismatch between that of the community and that of the school. Economic development in the area also raised the need for trained, competent tradespeople who were in extremely scarce supply. As the Innu approached the reality of self-management, there was an increased focus on the need for competent educators, health care workers, community leaders, etc. Consequently, as part of the preparations to create reserve status, the Innu requested a detailed study of the educational achievement of their children and their capacity to learn.

As a result, David Philpott and a team of colleagues from Memorial University of Newfoundland were invited to conduct an intensive study of the learning needs of the Innu youth. Over two school years (2002/3-2003/4) this team collected a wealth of data including attendance patterns for five years, surveys on oral language usage, attitudes/perceptions and aspiration for education, indices of social/behavioural concerns, risk factors for alcohol related disorders as well as various psychometric measures of academic achievement and cognitive ability. The study (Philpott et al., 2004) provides a comprehensive profile of the current status of education for these people as well as community attitudes towards the institution of schooling, as the Innu know it. Their work was founded on a careful review of the literature on culturally appropriate assessment and countless efforts were taken to establish, implement and review their methodology within a context of language/culture sensitivity. In all over $70 \%$ of the 908 school-aged Innu youth were assessed and the final report, An Educational Profile of the Learning Needs of Innu Youth, was released in November of 2004. It immediately received national media attention both for being the largest study of educational outcomes for Aboriginal youth in Canada and for its upsetting 
findings. It documents the profound failure of educational institutions to connect with this culture and the effect that this has had on socioeconomic needs. Equally plain was the need for a radical change in institutional structure as well as educational pedagogy.

The report presented a disturbing picture of the current standing of students in the present school system, who compromise half of the full population of the Labrador Innu.

A pattern emerged from these data indicating that most children begin falling behind as early as the first grade and continue a clear pattern of falling further behind grade/age expectations as they continue through school ... In the area of reading for example, $80 \%$ of seven year olds are one to two years behind grade level and the grade level discrepancy continues to increase to a point where $85 \%$ of 15 year olds were at least five years behind. A similar pattern is evident in mathematics, namely approximately $56 \%$ of seven year olds are one to two years behind and $100 \%$ of 15 year olds are at least five years behind. (Philpott et al., 2004: 14-15)

Lest we be tempted to blame the children, Philpott et al. (2005: 1) report from their study that cognition is not a salient factor in poor achievement:

An assessment of abilities shows that Innu students, as a group, have average intelligence. There is, however, a skew towards the low average range... one instrument reported that $31 \%$ of the students assessed scored in the average range and $41 \%$ scored in the low average range ... a second, more comprehensive measure of ability reported that $55 \%$ scored in the average range while $21 \%$ scored in the low average range ... A broader view of cognition suggests that $80 \%$ of Innu youth show significant strengths in the areas of visual/spatial, bodily/ kinaesthetic, naturalistic and inter/intrapersonal intelligence... The dominant finding is that the extremely poor student achievement results do not reflect a lack of inherent ability. However, what cannot be minimized is the equally clear indication that many students in Natuashish and some students in Sheshatshiu have learning difficulties. (Philpott et al., 2004: 16)

More relevant was the pattern of attendance, where the long-standing perception that Innu youth do not attend school was validated.

The vast majority of those who attend school do so sporadically. While a third of the full population do not attend school at all, another $17 \%$ do so less than $20 \%$ of the time. For the population who do attend, attendance approximates $54 \%$ of total school time in Natuashish ... and $45 \%$ in Sheshatshiu ... drop out begins in primary school and continues into adolescence with the result that only $30 \%$ of Innu youth enter high school where they then attend 20\% of the time. (Philpott et al., 2004: 12)

There was a strong correlation between academic achievement and school attendance, as demonstrated by a comparison with a small population of Innu youth (less than 5\%) who attend schools outside their community. Those 
students maintain $80 \%$ attendance and achieve much closer to grade level standing, despite having no significant difference in ability. It should be noted, however, that the parents of these children are more likely than others to have the resources to make it possible for their children to attend these schools and to facilitate the daily commute between communities.

More pertinent to achievement is the cultural relevance of the school. Qualitative research methods such as focus groups, interviews and observations identified that many Innu view the curriculum as being irrelevant to their lives or to their culture. These findings indicated that academic success is not seen as being linked with life success or even employment opportunities and that there is a pronounced mismatch between the culture of the community and that of the school. This cultural mismatch was named by the teachers who identified that the structure and routine of the school (hours of instruction, bells, regulations) were foreign to these children who appeared happier in the country than they do in contemporary classrooms. It was named by the students who reported more interaction with peers on the community streets than in the schools and who outlined a futility in attending school on consecutive days as teachers repeat curriculum for non-attenders. The mismatch was observed by the examiners who visited Innu schools which, with wall decorations such as the English Alphabet, pictures of Canadian Prime Ministers and the Queen and a noted absence of any Innu culture, looked remarkably like any other school in Canada. It was witnessed during classroom visits when a child was asked a question in English, the children discussed it among themselves in Innu-aimun and another child answered in English. It was evident in teachers who continuously saw students playing near the school but did nothing to encourage them to enter. It was also reported by community leaders who, despite being advocates for education, reported having had such negative school experiences themselves that they struggle with encouraging their children to attend.

Subsequently, the report concluded that 'low attendance for Innu youth is symptomatic of a larger issue - a mismatch between the cultural paradigms of the school and the community' (p. 14). Philpott et al. (2004) report that social disruptions in the communities routinely exacerbate poor attendance, at times lowering it to less than $20 \%$.

A number of years ago, there was an attempt to have more Innu control over the school and a system was devised whereby about half of the school day in the primary grades would be taught in Innu-aimun. Additionally, about ten Innu people were trained as certificated (minimally accredited to teach in the lower grades in their communities) teachers. However, there was very little support for those initiatives and the school remained a solidly Englishmedium institution. Complicating instruction would be a high rate of teacher turnover, struggles with recruitment and non-existent interaction between the white, English-speaking teachers and the community in which they worked. Teachers who work at Sheshatshiu lived in the neighbouring white community of Happy Valley/Goose Bay and commuted for 30 min each day, arriving at the school (as reported by the students) just prior to school start and departing shortly after school close. 
The chief factor in this mismatch, as indicated by the data from this study, is language. Language use surveys conducted with students, teachers and parents identify that $75 \%$ of parents and $67 \%$ of students speak only or mostly Innu-aimun. Likewise $77 \%$ of teachers reported awareness of this language clash yet only $44 \%$ of them reported they rarely or ever used interpreters. All communication between home and school, including newsletters, phone calls and report cards, were in English. Furthermore, less than $10 \%$ of teachers had any English as Second Language training and none could speak or understand Innu-aimun. The current educational system is one that recognises Innu-aimun as the first language of students and yet the staff and authorities choose to ignore this fact in pedagogical approaches to learning. Despite Innu oral community practices being clear, the institution of the school has not embraced them, leading to fractures in all aspects of school life. The major disparity between the role of literacy in the lives of the children and the culture of the school is completely unacknowledged. The high focus on English literacy in virtually all school subjects requires a vast amount of new learning for children who do not see literacy in use at all in their homes and very rarely in their community. This cultural mismatch is likely to be among the most important of the schools' failures to engage the children. In sum, despite Innu oral community practices being clear, the institution of the school has not embraced them.

Years of inadequate education has had a cumulative effect on the current adult population as well. As reported in An Educational Profile of the Learning Needs of Innu Youth (2004), achievement levels presently lag so dramatically that 'the researchers have grave concern for the readiness of current students to meet prescribed graduation criteria within the next five years' (Philpott et al., 2004: 15). Recent documents provided by community-based adult literacy programmes identify fewer than 20 adults in each community (18 in Natuashish and 13 in Sheshatshiu) have completed basic literacy programmes in the last 12 years. The initial study identified that another 17 students finished high school during the same time frame. It is critical that the communities recognise that basic literacy does not imply university/college readiness. The few Innu candidates who have completed high school and who are interested in pursuing careers in education will need additional academic support to ensure university readiness. Other Innu candidates will require literacy/numeracy training to reach high school equivalency levels to prepare for university entrance (Philpott et al., 2005: 8).

Under these circumstances, it is not surprising that, as shown in Table 1, the Innu in Labrador have a much higher percentage of people over the age of 25 with less than high school education compared with other groups (Statistics Canada, 2001).

Although census figures are not reliable for fine-tuned comparisons, the contrasts indicated here show that the Innu have fared much worse in education even than other Aboriginal peoples, and certainly than the rest of the population. These indicators by Statistics Canada reinforce the findings of Philpott et al . about the failure of schooling for Innu children and put them in a broader perspective. 
Table 1 Percent of adults with less than high school education by various groups: Focus on Innu of Labrador

\begin{tabular}{|l|c|}
\hline Population and age group & $\begin{array}{c}\text { \% of adults with less than } \\
\text { high school education }\end{array}$ \\
\hline Aboriginals in Sheshatshu, aged 25+ & 65.4 \\
\hline Aboriginals in Davis Inlet, aged 25+ & 70 \\
\hline Aboriginals in Newfoundland and Labrador, aged 25+ & 40 \\
\hline Newfoundland and Labrador, ages 20-64 & 31.7 \\
\hline All Aboriginals in Canada & 42 \\
\hline All Canada, ages 20-64 & 21.4 \\
\hline
\end{tabular}

Based on Statistics Canada, 2001 Census.

Overall then, the Innu of Labrador have strong resources in community functions of their language, mainly in the most intimate domains, but have not as a group accommodated strongly to the English-speaking environment or majority culture that is increasing around them, nor has the surrounding nonInnu community acknowledged the Innu culture or the Innu-aimun language reality in any significant way. The result is economic, educational and linguistic marginalisation of the Innu. Their traditional skills have been devalued in a money-based economy, so many are left with limited access to the new economy or to their previous ways of making a living. A combination of the massive challenge of adapting to new ways and lack of initiative or will on the part of the surrounding population in control of resources has left the Innu at an impasse.

\section{Reflections}

While the contemporary institution of schooling has had varied impacts on Aboriginal populations in Canada, with most groups continuing to struggle for quality learning opportunities for their youth while struggling to revitalise their language, the Innu of Labrador provide a paradoxical perspective. The extensive data that has emerged from the recent study on educational outcomes raises an interesting debate for the impact that a more successful educational system would have had on the Innu language and culture. Given that education has failed these people so blatantly, one is left to wonder whether their language and cultural identity would have otherwise survived, certainly to the extent that it has. Has the Innu tradition of language and culture survived by default - that is, as a resistance measure rather than a valued resource?

Furthermore, in terms of the approach(es) to schooling that the Innu have encountered since they settled in communities, it appears that any rhetoric on the part of school authorities about inclusion of pupils of different races, cultures and languages has not resulted in any effective adjustments to the curriculum or training of school personnel. In addition, school authorities 
have ignored their own indicators of the major failure of the Innu schools. Until the report by Philpott et al., blaming the victims has been the main argument on the part of non-Innu educators to account for the failure.

Despite this failure, it seems clear that Innu people continue to hold to positive expectations about the value of schooling for their children since they have settled in communities in Labrador in the 1960s and 1970s. However, the contrast between the linguistic, cultural and economic systems they lived by before settlement and those they met afterwards have been so great that the Innu have been highly stressed in all aspects of their lives. A combination of the degree of difference to be accommodated and minimal efforts to make accommodations on the part of forces that were responsible for the changes has resulted in social breakdown more than progress. Nonetheless, the Innu continue to use their traditional resources to mitigate the situation, but the incoming pressures are so strong and alien that a dilemma has resulted.

The results of the Philpott et al. study have pointed particularly to language and cultural differences as being the greatest factors in the failure of the schools and the children to engage with each other. School personnel and practices operate in English, while the children come to school from a community in which English has a very limited role. In addition, achievement in school is largely based on literate comprehension and production, while the children have little experience with the practical use of literacy in everyday life. The Labrador Innu schools have not even taken advantage of the pedagogical practices developed for use with immigrant children who do not speak the mainstream language when they enter Canadian schools. But Labrador Innu children are unlike immigrant children who generally are surrounded by a wide variety of spoken and written communication in English.

It is not surprising then that Philpott et al. (2004: 23) conclude that:

The learning needs of Innu youth are profound and urgent. They can only be addressed by fundamental change. Tinkering with the existing system will have little effect if any. By the time the futility of halfmeasures is realized, another generation of youth may be lost. While this report identifies areas for significant change it withholds specific recommendations, preferring that there be a dialogue among the stakeholders, most importantly inclusive of the Innu themselves, before decisions are made. Imposed change and educational approaches run the risk of further complicating existing problems.

If the hopes of the parents and the expectations that the school will support Innu children's integration into the dominant Canadian structure are to be fulfilled, then the schools will have to work hard to cross this divide and meet the Innu people, as they exist. At this crucial juncture, when the roles of the federal and provincial governments and the Innu communities are being reexamined, it is essential that all parties make significant adjustments to their knowledge base, ways of operating and use of resources. The immediacy of this concern was underscored by two Innu mothers, both strong leaders in their communities, whose children were in the community daycare programme. On discussing the significance of language of instruction, these 
woman reported that both their children, who are now immersed in an English language environment, view English as their first language and are 'unable to speak with their grandparents'.

If schooling is to have a positive role in resolving this culture and language clash, educational authorities will have to find ways of including Innu perspectives on learning. Governments at several levels will have to put many more resources into finding effective teaching approaches rather than sweeping the situation under the rug as politically insignificant. Innu families and community leadership will have to find ways of including some of the knowledge and values of modern Western society into the fabric of their culture.

\section{Correspondence}

Any correspondence should be directed to Barbara Burnaby, Faculty of Education, Memorial University of Newfoundland, St John's, Newfoundland and Labrador, A1B 3X8, Canada (bburnaby@mun.ca).

\section{Note}

1. In this paper, we use the term 'Aboriginal peoples' to refer in general to all people descended from the inhabitants of North America before the immigration of others starting about $1500 \mathrm{AD}$. There is a rather bewildering variety of other terms (e.g. Native peoples, First Nations, Métis, Inuit) that reflect ethnic, linguistic and political distinctions. For present purposes, we use 'Aboriginal' as generic to make comments on the group as a whole. The Innu of Labrador's history of its political relationship with the federal and provincial governments, for example, sets it apart from most First Nations peoples in Canada.

\section{References}

Armitage, P. (1997) The Innu. On WWW at www.heritage.nf.ca/aboriginal/innu.html. Accessed 18.10.05.

Assembly of First Nations (1988) Tradition and Education: Towards a Vision of our Future: A Declaration of First Nations Jurisdiction over Education. Summerstown, Ontario: Assembly of First Nations.

Assembly of First Nations (1990) Towards Linguistic Justice for First Nations. Ottawa: Education Secretariat, Assembly of First Nations.

Backhouse, C. and McRae, D. (2002) Report to the Canadian Human Rights Commission on the Treatment of the Innu of Labrador by the Government of Canada. Ottawa: Faculty of Law, University of Ottawa.

Bragdon, K. (2000) Native languages spoken and written: Views from southern New England. In E.G. Gray and N. Fiering (eds) The Language Encounter in the Americas, 1492-1800: A Collection of Essays (pp. 173-188). New York, Oxford: Berghahn Books.

Brehaut, W. (1984) Trends in the history of Ontario education. In H. Oliver, M. Holmes and I. Winchester (eds) The House that Ryerson Built: Essays in Education to Mark Ontario's Bicentennial (pp. 7-17). Toronto: OISE Press.

Burnaby, B. (1980) Languages and their Roles in Educating Native Children. Toronto: OISE Press.

Burnaby, B. (1985) Promoting Native Writing Systems in Canada. Toronto: OISE Press.

Burnaby, B. (1999) Policy on Aboriginal languages in Canada: Notes on status planning. In L.P. Valentine and R. Darnell (eds) Theorizing the Americanist Tradition (pp. 299-314). Toronto: University of Toronto Press.

Burnaby, B. (2002) First Nations Language and Culture Programs in Provincial Schools. Ottawa: Indian and Northern Affairs Canada. 
Burnaby, B. and Beaujot, R. (1986) The Use of Aboriginal Languages in Canada: An Analysis of 1981 Census Data. Ottawa: Department of the Secretary of State.

Burnaby, B., James, C.E. and Regier, S. (2000) The Role of Education in Integrating Diversity in the Greater Toronto Area. Toronto: Joint Centre of Excellence for Research on Immigration and Settlement - Toronto, Working Papers Series.

Council of Ministers of Education (2004) Quality Education for All Young People: Challenges, Trends, and Priorities. On WWW at www.cmec.ca/international/ unesco/ice47.en.stm. Accessed 14.03.06.

Department of Education, Newfoundland and Labrador (2005) Indicators 2005: A Report on Schools. St. John's, NL: Department of Education, Government of Newfoundland and Labrador.

Drapeau, L. (1984a) Le traitement de l'information chez les Montagnais. Recherches amérindiennes au Québec 14 (4), 24-35.

Drapeau, L. (1984b) Une éxperience d'implantation du montagnais comme langue d'enseignment à Betsiamites. Recherches amérindiennes au Québec 14 (4), 57-61.

Drapeau, L. (1992) Rapport final sure le projet-pilot de Betsiamites: Étude longitudinale (1982-1990). Montreal: Département de linguistique, Université du Québec à Montréal.

Drapeau, L. (1995) Code-switching in caretaker speech and bilingual competence in a native village of Northern Quebec. International Journal of the Sociology of Language $113,157-164$.

Encyclopaedia of Newfoundland, Volume 5 (1997) St. John's, NF: Harry Cuff.

Francis, N. and Reyhner, J. (2002) Language and Literacy Teaching for Indigenous Education: A Bilingual Approach. Clevedon: Multilingual Matters.

Greenfield, B. (2000) The Mi'kmaq hieroglyphic prayer book: Writing and Christianity in Maritime Canada, 1675-1921. In E.G. Gray and N. Fiering (eds) The Language Encounter in the Americas, 1492-1800: A Collection of Essays (pp. 189-211). New York, Oxford: Berghahn Books.

Hart, W.B. (2000) Mohawk schoolmasters and catechists in mid-eighteenth-century Iroquoia: An experiment in fostering literacy and religious change. In E.G. Gray and N. Fiering (eds) The Language Encounter in the Americas, 1492-1800: A Collection of Essays (pp. 230-257). New York, Oxford: Berghahn Books.

Hawthorn, H.B. (1967) A Survey of the Contemporary Indians of Canada: Economic Political and Educational Needs and Policies (Vol. II). Ottawa: Indian Affairs Branch.

Howatt, A.P.R. and Widdowson, H.G. (2004) A History of English Language Teaching (2nd edn). Oxford: Oxford University Press.

Hughes, K. (1990) "You Took My Talk": Aboriginal Literacy and Empowerment. Ottawa: House of Commons, Standing Committee on Aboriginal Affairs.

Kirkness, V.J. (1992) First Nations and Schools: Triumphs and Struggles. Toronto: Canadian Education Association.

MacPherson, J.C. (1991) MacPherson Report on Tradition and Education: Towards a Vision of our Future. Ottawa: Indian Affairs and Northern Development.

Mailhot, J. (1985) Implementation of mother-tongue literacy among the Montagnais: Myth or reality. In B. Burnaby (ed.) Promoting Native Writing Systems in Canada (pp. 17-26). Toronto: OISE Press.

Mailhot, J. (1997) In the Land of the Innu: The People of Sheshatshit (A. Harvey, trans.) St. John's, NL: ISER Books.

McCann, P. (1998) Education: Society and Culture: Newfoundland and Labrador Heritage. On WWW at http:/ / www.heritage.nf.ca/society/education.html. Accessed 21.12.06.

McGrath, R. (1991-92) The history of Inuit literacy in Labrador. The Newfoundland Quarterly 89, 35-40.

National Indian Brotherhood (1972) Indian Control of Indian Education. Ottawa: National Indian Brotherhood.

Norris, M.J. (1998) Canada's Aboriginal languages. Canadian Social Trends Winter, 8-16. Statistics Canada catalogue no. 11-008, Ottawa. 
Office of the Auditor General of Canada (2004) Indian and Northern Affairs Canada: Education program and post-secondary student support. On WWW at http://www. oag-bvg.gc.ca/domino/reports.nsf/html/20041105.ce.html. Accessed 21.12.06.

Ontario Department of Education (1968) Living and Learning: The Report of the Provincial Committee on Aims and Objectives of Education in the Schools of Ontario. Toronto: Ontario Department of Education.

Phillipson, R. (1992) Linguistic Imperialism. Oxford, UK: Oxford University Press.

Philpott, D.F. and Nesbit, W.C. (2002) Legislative provisions for special education in Newfoundland and Labrador. Exceptional Education Canada 11 (2-3), 137-157.

Philpott, D.F., Nesbit, W.C., Cahill, M.F. and Jeffery, G.H. (2004) An Educational Profile of the Learning Needs of Innu Youth. St. John's, NL: Memorial University of Newfoundland.

Philpott, D.F., Nesbit, W.C., Cahill, M.F. and Jeffery, G.H. (2005) Recommendations for an Effective Model of Innu Education. St. John's, NL: Memorial University of Newfoundland.

Press, H. (1995) Davis Inlet in crisis: Will the lessons ever be learned? Canadian Journal of Native Studies 15 (2), 187-209.

Rowe, F.W. (1976) Education and Culture in Newfoundland. Scarborough, ON: McGrawHill Ryerson.

Royal Commission on Aboriginal Peoples (1996) Royal Commission Report on Aboriginal Peoples. Ottawa: Department of Indian Affairs and Northern Development.

Samson, C. (2000/2001) Teaching lies: The Innu experience of schooling. London Journal of Canadian Studies 16, 84-102.

Statistics Canada (2001) 2001 Community Profiles (St. John's, Nerwfoundland and Labrador, Canada). On WWW at http://www.statcan.ca/. Accessed 23.7.03.

Statistics Canada (2003a) Aboriginal Population Profiles (Sheshatshu, Davis Inlet, Newfoundland and Labrador, Canada). On WWW at http://www.statcan.ca/. Accessed 23.7.03.

Statistics Canada (2003b) 2001 Census Table 97F0007XCB01009. On WWW at http:// www.statcan.ca/. Accessed 23.7.03.

Tanner, A., Kennedy, J.C., McCorquodale, S. and Inglis, G. (1994) Aboriginal Peoples and Governance in Newfoundland and Labrador: A Report for the Governance Project, Royal Commission on Aboriginal Peoples. St. John's, Newfoundland: Memorial University of Newfoundland.

Task Force on Aboriginal Languages and Cultures (2005) Towards a New Beginning: A Foundational Report for a Strategy to Revitalize First Nation, Inuit and Métis Languages and Cultures. Ottawa: Department of Canadian Heritage.

Tschantz, L. (1980) Native Languages and Government Policies: An Historical Examination. London, Ontario: Centre for Research and Teaching of Canadian Native Languages, The University of Western Ontario. 